\title{
PENGARUH PELATIHAN HAND ONLY CPR SISWA SMK KESEHATAN DALAM PENANGANAN HENTI JANTUNG
}

\author{
THE EFFECTIVITY OF HAND ONLY CPR \\ TRAINING FOR STUDENT OF HEALTH \\ VOCATIONAL SCHOOLS IN HANDLING CARDIAC \\ ARREST
}

\author{
A.A Istri Dalem Hana Yundari ${ }^{1}$, I Nyoman Asdiwinata ${ }^{2}$ \\ Keperawatan Gawat Darurat, Program Studi Ilmu Keperawatan, STIKes Wira Medika Bali1 ${ }^{1,2}$
}

\begin{abstract}
ABSTRAK
Latar belakang: Out-of-Hospital Cardiac Arrest (OHCA) merupakan kondisi gangguan jantung yang sering mengancam nyawa seseorang. Penanganan pada kejadian tersebut sebanyak 40,1 \% mendapatkan tindakan Resusitasi Jantung Paru (RJP) oleh orang - orang yang ada di sekitar korban dengan angka keberlangsungan hidup korban yang mendapatkan tindakan RJP dilokasi kejadian mencapai 9,5\%. Hand only CPR merupakan fondasi dari pertolongan terhadap henti jantung dan merupakan aspek fundamental dari Basic Life Support (BLS) dengan mengenali Sudden Cardiac Arrest (SCA), mencari pertolongan emergency, dan kompresi dada segera yang dapat dilakukan oleh orang awam. Siswa SMK Kesehatan merupakan bagian dari orang awam yang pada jenjang pendidikan tersebut belum memperoleh kompetensi penanganan henti jantung melalui RJP. Tujuan. Tujuan penelitian ini adalah untuk mengetahui efektifitas dan pengaruh pelatihan hand only cpr pada siswa smk kesehatan dalam penanganan henti jantung. Metode: Kuantitatif korelasi dengan uji bivariat pre-post design tanpa control melalui metode ceramah dan simulasi menggunakan manikin Resusitasi Jantung Paru (RJP). Hasil: Uji analisis Mac Nemar: $p=0,000(\mathrm{p}<0,05)$ dengan kategori sebagian besar $(24$ orang $)$ memiliki keterampilan baik setelah memperoleh pelatihan Hand Only CPR. Kesimpulan: Terjadi hubungan bermakna sebelum dan sesudah diberikan pelatihan hand only $C P R$.
\end{abstract}

Kata Kunci: Henti Jantung, Hand only $C P R$, Keterampilan.

\begin{abstract}
Background: Out-of-Hospital Cardiac Arrest (OHCA) is a heart disorder condition that often threatens a person's life. Handling in this incident as much as $40.1 \%$ received Cardiac Pulmonary Resuscitation (CPR) by people around the victim with the survival rate of victims who received CPR action at the location of the incident reaching $9.5 \%$. Hand only $\mathrm{CPR}$ is the foundation to handling for cardiac arrest and as a fundamental aspect of Basic Life Support (BLS) by recognizing Sudden Cardiac Arrest (SCA), seeking emergency help,
\end{abstract}


DOI: https://doi.org/10.36376/bmj.v8i1

and immediate chest compressions that can be performed by common people. Health Vocational School students are part of ordinary people who at this level of education have not yet obtained competency in handling cardiac arrest through CPR. Purpose. The purpose of this study was to determine the effectiveness and effect of hand only CPR training on Health Vocational School students in the handling cardiac arrest. Methods: Quantitative correlation with bivariate pre-post design test without control through lecture and simulation methods using Cardiac Resuscitation (CPR) panthom. Results: Mac Nemar's analysis test: $\mathrm{p}=0.000(\mathrm{p}<0.05)$ with the category most $(24$ people $)$ had good skills after receiving Hand Only CPR training. Conclusion: There was a significant relationship before and after being givenhand only CPR training.

Keyword: Cardiac Arrest, Hand Only CPR, Skills.

\begin{tabular}{ll}
\hline Alamat Korespondensi & : STIKes Wira Medika Bali \\
Email & : hanayundari@gmail.com
\end{tabular}

\section{PENDAHULUAN}

Out-of-Hospital Cardiac Arrest (OHCA) atau yang lebih dikenal dengan henti jantung yang terjadi di luar rumah sakit, merupakan kondisi yang seringkali mengancam nyawa seseorang. Prevalensi henti jantung yang terjadi di luar rumah sakit di beberapa negara mengalami peningkatan. American Heart Association (AHA) pada tahun 2015 mempublikasikan dalam Heart Disease and Stroke Statistics, disebutkan bahwa insiden OHCA di Amerika mencapai 359.400 orang. Penanganan yang dilakukan pada jumlah tersebut yaitu sebanyak 40,1\% mendapatkan tindakan Resusitasi Jantung Paru (RJP) oleh orang - orang yang ada di sekitar korban, dan didapatkan bahwa angka keberlangsungan hidup dari korban yang mendapatkan tindakan RJP dilokasi kejadian mencapai 9,5 \% (AHA, 2015). Keberadaan dan jumlah masyarakat yang memberikan pertolongan RJP ketika menemui korban yang mengalam henti jantung secara mendadak masih tergolong rendah dan bervariasi dengan tingkat terendah yaitu $1 \%$ dan tertinggi yaitu sekitar $44 \%$ (Sasson et al, 2013).

Aspek fundamental dari Bantuan Hidup Dasar (BHD) yaitu mengenali Sudden Cardiac Arrest (SCA), dan mencari pertolongan secara emergensi, Resusitasi Jantung Paru (RJP) segera, dan tindakan defibrilasi cepat dengan Automated Defibrillator External (AED) yang dapat dilakukan oleh tenaga medis terlatih. Henti jantung tidak selalu disadari secara jelas terutama bagi orang awam. Hal ini dapat menyebabkan keterlambatan atau kegagalan meminta pertolongan darurat atau dalam memulai RJP. Hand only $C P R$ adalah fondasi dari pertolongan terhadap henti jantung. Panduan bantuan hidup dasar ini dapat berfokus pada mengenali henti jantung dengan penanganan yang tepat pada berbagai latar belakang penolong dan tidak hanya berfokus pada penolong dengan latar belakang tenaga medis. 
Keterampilan adalah suatu kemampuan dan kapasitas yang diperoleh melalui usaha yang disengaja, sistematis, dan berkelanjutan untuk secara lancar dan adaptif melaksanakan aktivitas-aktivitas yang kompleks atau fungsi pekerjaan yang melibatkan ide-ide (keterampilan kognitif), hal-hal (keterampilan teknikal), dan orang-orang (keterampilan interpersonal). Pemberian pelatihan Hand Only CPR tepat diberikan pada orang awam dikarenakan pada teknik tersebut hanya memerlukan tindakan kompresi pada jantung sebagai upaya memepertahankan sirkulasi darah pada tubuh korban sehingga diharapkan supply oksigen dalam darah tetap dapat terdistribusi ke seluruh sel dan jaringan.

Tujuan penelitian ini adalah untuk mengetahui efektifitas dan pengaruh pelatihan hand only CPR pada siswa smk kesehatan dalam penanganan henti jantung. Mengingat keterampilan Hand Only CPR ini sangat penting untuk dikuasai oleh semua lapisan masyarakat, dan belum banyak penelitian yang mengangkat hal ini, maka dilihat penting untuk mengajarkan dari dini dan dimulai dari sekolah.

\section{METODE PENELITIAN}

Penelitian ini merupakan penelitian kuantitatif korelasional Pre-Post Design Without Control Group menggunakan teknik tutorial, dan simulasi. Media yang digunakan yaitu manikin Resusitasi Jantung Paru (RJP) dalam melakukan simulasi Hand Only CPR dan menggunakan lembar observasi ketepatan tata laksana Hand Only CPR dalam mengukur keterampilan sampel penelitian. Populasi pada penelitian ini adalah Siswa SMK Kesehatan PGRI Denpasar dengan jumlah sampel 70 orang siswa. Teknik sampling menggunakan Probability Simple Random Sampling.

\section{HASIL DAN PEMBAHASAN}

\section{Hasil}

Tabel 1

Karakteristik Usia dan Jurusan Responden Siswa Kelas X SMK Kesehatan PGRI Denpasar

\begin{tabular}{ccc}
\hline & $\mathrm{n}$ & $\%$ \\
\hline Usia (tahun) & 7 & 10,0 \\
15 & 41 & 58,6 \\
16 & 22 & 31,4 \\
17 & & \\
\hline Jurusan & 46 & 65,7 \\
Keperawatan & 24 & 34,3 \\
\hline
\end{tabular}


Hasil pada tabel 1 dapat dilihat bahwa sebagian besar usia siswa 16 tahun sebanyak 41 orang (58\%) dan mayoritas siswa merupakan siswa jurusan keperawatan yaitu sebanyak 46 orang $(65,7 \%)$.

Tabel 2

Hasil Uji Analisis Hubungan Keterampilan Siswa SMK Keshatan PGRI Denpasar Kelas X sebelum dan sesudah diberikan pelatihan Hand only CPR

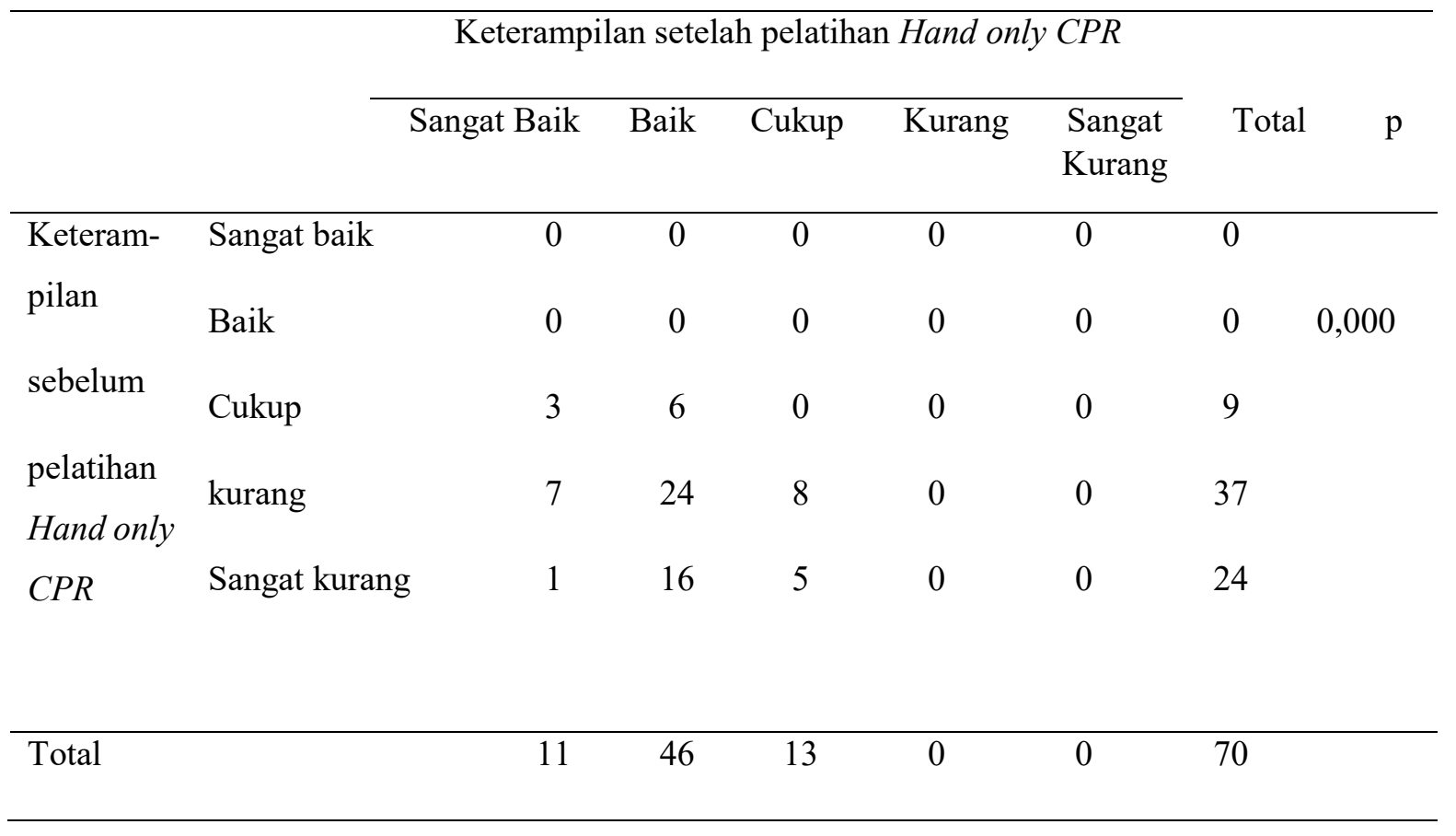

Hasil crosstab pada tabel 2 menunjukkan tingkatan keterampilan terbesar ada pada kategori sebelum diberikan pelatiahn hand only $C P R$ dengan kategori kurang dan sesudah diberikan pelatihan hand only $C P R$ pada kategori baik sebanyak 24 orang. Sedangkan hasil uji analisis Mac Nemar diperoleh nilai $p=0,000(\mathrm{p}<0,05)$ yang berarti terdapat hubungan bermakna sebelum dan sesudah diberikan pelatihan hand only CPR.

\section{Pembahasan}

Responden penelitian yang merupakan siswa SMK Kesehatan kelas X merupakan siswa yang belum mendapatkan teori ataupun praktik tentang materi kegawatdaruratan khususnya penangana pasien henti jantung, tentu saja peserta masih tergolong awam bahkan tabu untuk paham dan mengetahui serta mampu menangani kondisi henti jantung pada pasien. Hasil peneltian menunjukkan hasil dari keterampilan responden dalam melakukan tindakan hand only CPR memperlihatkan bahwa tingkat keterampilan terbesar ada pada kategori sebelum diberikan pelatiahan hand only CPR dengan kategori kurang dan sesudah diberikan 
pelatihan hand only CPR pada kategori baik sebanyak 24 orang. Setelah diberikan materi tentang fisiologis jantung dan konsep patologis dari henti jantung, responden diberikan contoh tindakan hand only $C P R$ dengan menggunakan media manikin Resusitasi Jantung Paru (RJP) yang diperagakan oleh peneliti sebagai contoh, setelah itu peserta diberikan untuk mencoba melakukan tindakan sebelum dilakukan penilaian keterampilan.

Memberikan kesempatan peserta untuk melakukan tindakan setelah diberikan contoh merupakan salah satu teknik dalam sebuah pembelajaran. Sesuai dengan teori belajar, menurut Bloom (1996), seorang ahli pendidikan, membuat klasifikasi (taxonomy), kecakapan berfikir pada manusia dapat dibagi dalam 6 kategori yaitu Pengetahuan (knowledge) mencakup ketrampilan mengingat kembali faktor-faktor yang pernah dipelajari, Pemahaman (comprehension), meliputi pemahaman terhadap informasi yang ada, penerapan (application) mencakup ketrampilan menerapkan informasi atau pengetahuan yang telah dipelajari ke dalam situasi yang baru, analisis (analysis) meliputi pemilahan informasi menjadi bagian-bagian atau meneliti dan mencoba memahami struktur informasi, sintesis (synthesis) mencakup menerapkan pengetahuan dan ketrampilan yang sudah ada untuk menggabungkan elemen-elemen menjadi suatu pola yang tidak ada sebelumnya, dan evaluasi (evaluation) meliputi pengambilan keputusan atau menyimpulkan berdasarkan kriteria-kriteria yang ada biasanya pertanyaan memakai kata: pertimbangkanlah, bagaimana kesimpulannya (Nikodemus, 2019)

Melalui proses pelatihan tersebut sudah mencakup keseluruhan proses belajar sehingga hasil pengukuran menunjukkan ada perubahan peningkatan keterampilan peserta (siswa) dalam kompetensi menangani pasien dengan henti jantung. Hasil penelitian tersebut menampilkan bahawa pada siswa yang sebelum diberikan pelatihan hand only CPR memiliki kemampuan yang kurang dikarenakan pada jenjang tingkat Pendidikan SMK khususnya pada kelas 10, siswa belum pernah mendapatkan materi tentang penanganan henti jantung, walaupun beberapa anak telah mampu melakukan tindakan namun tidak sepenuhnya benar sesuai dengan rekomendasi AHA tentang tindakan hand only CPR.

\section{SIMPULAN DAN SARAN}

\section{Simpulan}

Ada pengaruh pemberian pelatian hand only $C P R$ terhadap keterampilan siswa SMK Kesehatan PGRI tentang penanganan henti jantung. Sebagian besar hasil menampilkan terjadi peningkatan keterampilan dalam simulasi pelaksanaan Hand Only CPR sebelum diberikan pelatihan sebelum intervensi dengan kategori kurang dan sesudah intervensi pada kategori baik.

\section{Saran}

Mengingat keterampilan Hand Only CPR ini sangat penting untuk dikuasai oleh semua lapisan masyarakat, dan belum banyak penelitian yang mengangkat hal ini, maka dilihat penting untuk mengajarkan dari dini dan dimulai dari sekolah. 
Pelaksanaan Pelatihan hand only $C P R$ bagi masyarakat awam diharapkan bisa dilanjutkan pada sektor-sektor yang lebih vital seperti perkantoran, swalayan, banjarbanjar ataupun tempat umum lainnya yang memiliki potensi kejadian gawat darurat yang cukup tinggi.

\section{DAFTAR PUSTAKA}

American Heart Association (AHA). (2010). Guidelines CPR ECC 2010. Higlights of the 2010 .

American Heart Association (2015). Cardiac Arrest Statistic. American Heart Association, Inc. Berg. (2015).

American Heart Associaton cardiac arrest survival summit. (2016). Circulation. DOI : 10.1161/CIR.0b013e31821d79f3

Role of mouth-to-mouth rescue breathing in bystander cardiopulmonary resuscitation for asphyxial cardiac arrest. Crit Care Med.28(suppl):N193N195.

Handley AJ. (2002). Teaching hand placement for chest compression —a simpler technique.Resuscitation;53: 29-36

Johnston TC, Clark MJ, Dingle GA, and FitzGerald G. (2003). Factors influencing Queenslandes' willingness to perform bystander cardiopulmonary resuscitation. Resuscitation $56.67-75$

Kawano et al. (2011). Tutorial videos of bioinformatics resources: online distribution trial in Japan named TogoTV. Briefings In Bioinformatics. Vol 13. No 2. $258-268$

Kundra P, Dey S, Ravishankar M. (2000). Role of dominant hand position during external cardiac compression. Br J Anaesth ;84:491-3.

Machin, S., \& McNally, S. (2008). The literacy hour. Journal of Public Economics, 92(5-6), 1441-1462.

Neumar et al. (2011). Implementation strategies for improving survival after out of hospital cardiac arrest in the United State : Consensus recommendtaions from the 2009

Nikodemus. (2019). Relationship Relationship Of Internal Student Factors With Student Achievements. Bali Medika Jurnal. Vol 6 no 2.

Nikandish et al. (2005). Cpmparison of basic life support (BLS) video self instructional system and traditional BLS training in first year nursing students. Journal of Medical Education. Vol 7 No 1

Mathew,R, Sahu,A.K, Thakur,N; Aaditya Katyal,dkk. (2020). Hands-Only Cardiopulmonary Resuscitation Training For Schoolchildren: A comparison study among different class groups.20(4).186-192 